\title{
Innovative Concrete Repairing Technique Using Post Tensioning Steel Straps
}

\author{
Chau-Khun $\mathrm{Ma}^{1,{ }^{*}}$, Sofrie Chin Siew Yung ${ }^{1}$, Nazirah Apandi ${ }^{1}$, Abdullah Zawawi Awang ${ }^{1}$, \\ and Wahid Omar $^{2}$ \\ ${ }^{1}$ Department of Structure and Materials, Faculty of Civil Engineering, Universiti Teknologi \\ Malaysia, 81310, Johor Bahru, Malaysia \\ ${ }^{2}$ Office of Chancellery, Universiti Teknologi Malaysia, 81310, Johor Bahru, Malaysia
}

\begin{abstract}
In this paper, innovative technique using low-cost recycled steel straps confinement to repair load-induced damaged high-strength concrete (HSC) columns were studied. This paper explains the effects of repairing technique using post tensioning steel straps. A series of experimental test was carried out to investigate the stress-strain relationships of such concrete. A total of 6 HSC columns were compressed $50 \%$ of their ultimate strength, then repaired by using steel straps. The proposed repairing technique significantly improved the performance of damaged concrete columns, in both strength and ductility. It was evidenced from this study that the steel strapping confining technique is effective in repairing of damaged HSC columns but ensured reasonable operating costs.
\end{abstract}

\section{Introduction}

Recently, the suitability of using steel straps as confining material has been experimentally investigated [1-5]. The steel straps used in these studies are recycled steel straps which are commonly used as packing strands for exporting good crates. The benefit of using steel straps as confining material, aside from its cost effectiveness, is it allows post-tensioning confining pressure around concrete which ensure fully effective use of the confining material [6-8]. As being reported previously, the passive type of confining materials which are activated by the dilation of the concrete, not reaching their ultimate strain at the ultimate failure. This problem is more severe for high strength concrete (HSC) which generally possess lower Poisson's ratio [9-12]. During the confining works, the steel straps were pulled using tensioner around the concrete up to certain level of strain to ensure even very small dilation of concrete can initiate the confining effects. The confining method using post-tensioned steel straps were evidenced to be effective in increasing the ductility and strength of HSC which is brittle and non-ductile in nature [13].

The current study extends the state-of-art of confining works using steel straps to repair and rehabilitate damaged HSC. It is believed that the proposed model can provide a robust platform for the engineers, academicians, consultants and building pathologists in the

* Corresponding author: machaukhun@gmail.com 
design of such repair works. The use of steel straps is still limited in the industry although the use of steel straps is effective in repairing structure.

\section{Load induced specimen}

A total of 6 HSC cylinders with diameter of $100 \mathrm{~mm}$ and height of $200 \mathrm{~mm}$ were prepared in this study. The targeted concrete compressive strength is $50 \mathrm{MPa}$ with mix proportions as shown in Table 1. Corresponding concrete cubes were prepared alongside with the specimens for the determination of concrete compressive strength. Based on the analysis of the cube tests, the average concrete compressive strength is $50.27 \mathrm{MPa}$ with standard deviation of $4.6 \mathrm{MPa}$ at the age of 28 days after curing. The specimens were then preloaded to damage the cylinders to simulate the situations where concrete were damaged at $50 \%$ of axial load capacity. The damaged specimens were repaired using two different repairing schemes to investigate the differences in their effectiveness. The first scheme is repair using surface grouting only with mortar that has prescribed mix of 1:1:0.5 (cement: sand: water). No attempts to fill the internal crackings to avoid changes in the specimen properties. Second scheme is repair using surface grouting and then confine using posttensioned steel straps. The specimens were confined with different spacing and confinement layers of steel straps to achieve different confining volumetric ratio, $\rho_{\mathrm{v}}$. The different in spacing and layers of confining steel straps will be addressed in confining volumetric ratio hereafter for simplicity in the design which is more favourable in practical. The details of the specimens are tabulated in Table 2.

Table 1. Mix portions of $1 \mathrm{~m}^{3}$ concrete

\begin{tabular}{|c|c|c|}
\hline Material & Type & Quantity \\
\hline OPC $(\mathrm{kg})$ & Portland & 409 \\
\hline Sand $(\mathrm{kg})$ & River sand & 806 \\
\hline Aggregate $(\mathrm{kg})$ & $10 \mathrm{~mm}$ & 1025 \\
\hline Superplasticizer $(l)$ & Glenium C380 & 16 \\
\hline Water $(\mathrm{kg})$ & Tap water & 162 \\
\hline
\end{tabular}

\section{Steel Wrapping Works}

In this study, the spacing between the steel straps were fixed into $10 \mathrm{~mm}$ and $30 \mathrm{~mm}$. The specimens were confined with 1, 2 and 3 layers steel straps. Steel straps, tensioner used and confined specimens are shown in Fig. 1. All confined specimens were confined from end to end to prevent concrete crushing near the load platens.

\section{Load procedure}

The compressive strength of the concrete was determined by uniaxial compression test using 'Tinius Olsen' compression machine that has a maximum load capacity of 2,500 kN. All tests were conducted in the Laboratory of structure and materials in Universiti Teknologi Malaysia (UTM). The loading is displacement controlled with constant rate of $0.01 \mathrm{~mm} / \mathrm{s}$ for all specimens.During the test, the axial load and vertical strains were recorded by an automatic data acquisition through data logger to monitor the stress-strain behaviour of the specimens. The variations of axial strains of the specimen were measured by two $50 \mathrm{~mm}$ omega strain gauges attached at both sides of the specimen. The variations in readings between the two omega strain gauges were monitored closely and the testing was stopped immediately in case the variations exceeding $10 \%$, indicating the specimen 
was not aligned in the center of the platen. The specimen was then re-positioned and centered again until the variation is less than $10 \%$. The specimen was monotonically loaded until the specimen failed. Fig. 2 shows the schematic test setup and instrumentations.

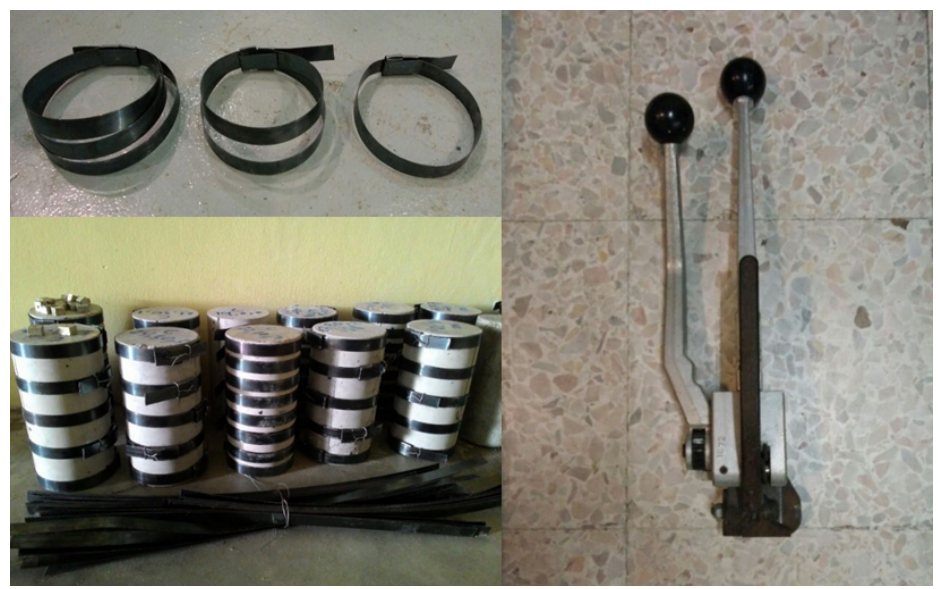

Fig. 1. Steel strapping confinement (a) Steel straps; (b) Confined specimens; (c) Tensioner

Table 2. Details of tested specimens

\begin{tabular}{|c|c|c|c|c|c|c|c|c|c|c|}
\hline $\begin{array}{l}\text { Specimen } \\
\text { ID }\end{array}$ & $\begin{array}{l}\text { Steel } \\
\text { Straps } \\
\text { layer }\end{array}$ & $\begin{array}{l}\text { Spacing } \\
(\mathrm{mm})\end{array}$ & $\begin{array}{l}\text { Pre- } \\
\text { damaged } \\
\text { level } \\
(\%)\end{array}$ & $\begin{array}{l}\text { Ultimate } \\
\text { load (kN) }\end{array}$ & $\begin{array}{l}\text { Ultimate } \\
\text { displacement } \\
(\mathrm{mm})\end{array}$ & $\begin{array}{l}\text { Ultimate } \\
\text { stress, } \\
f_{c u} \\
\left(\mathrm{~N} / \mathrm{mm}^{2}\right)\end{array}$ & $\begin{array}{l}\text { Degree of } \\
\text { damage, } \\
\delta(\%)\end{array}$ & $\begin{array}{l}\text { Confining } \\
\text { volumetric } \\
\text { ratio, } \rho_{\mathrm{v}}\end{array}$ & $\begin{array}{l}\text { Confinement } \\
\text { pressure, } f_{i}\end{array}$ & $\begin{array}{l}\text { Repairing/ } \\
\text { Strengthening } \\
\text { Scheme }\end{array}$ \\
\hline $\begin{array}{l}\text { C50-0-0 } \\
(+50)\end{array}$ & - & - & +50 & 162.6 & 0.46 & 50.2 & $0.05^{\mathrm{a}}$ & 0 & $0^{\circ}$ & Surface grouting \\
\hline $\begin{array}{l}\text { C50-30-1 } \\
(+50)\end{array}$ & 1 & 30 & +50 & 421.1 & 0.69 & 53.6 & $0.05^{a}$ & 0.27 & $0.05^{\circ}$ & $\begin{array}{l}\text { Surface grouting + } \\
\text { steel strapping }\end{array}$ \\
\hline $\begin{array}{l}\text { C } 50-10-1 \\
(+50)\end{array}$ & 1 & 10 & +50 & 420.6 & 0.85 & 53.5 & $0.05^{\mathrm{a}}$ & 0.48 & $0.09^{\circ}$ & $\begin{array}{l}\text { Surface grouting + } \\
\text { steel strapping }\end{array}$ \\
\hline $\begin{array}{l}\text { C50-30-2 } \\
(+50)\end{array}$ & 2 & 30 & +50 & 458.7 & 1.50 & 63.9 & $0.05^{\mathrm{a}}$ & 0.53 & $0.10^{\circ}$ & $\begin{array}{l}\text { Surface grouting + } \\
\text { steel strapping }\end{array}$ \\
\hline $\begin{array}{l}\text { C50-30-3 } \\
(+50)\end{array}$ & 3 & 30 & +50 & 521.5 & 1.63 & 66.4 & $0.05^{\mathrm{a}}$ & 0.80 & $0.15^{\circ}$ & $\begin{array}{l}\text { Surface grouting + } \\
\text { steel strapping }\end{array}$ \\
\hline $\begin{array}{l}\text { C50-10-2 } \\
(+50)\end{array}$ & 2 & 10 & +50 & 563.9 & 2.64 & 91.8 & $0.05^{\mathrm{a}}$ & 0.96 & $0.18^{\circ}$ & $\begin{array}{l}\text { Surface grouting + } \\
\text { steel strapping }\end{array}$ \\
\hline
\end{tabular}

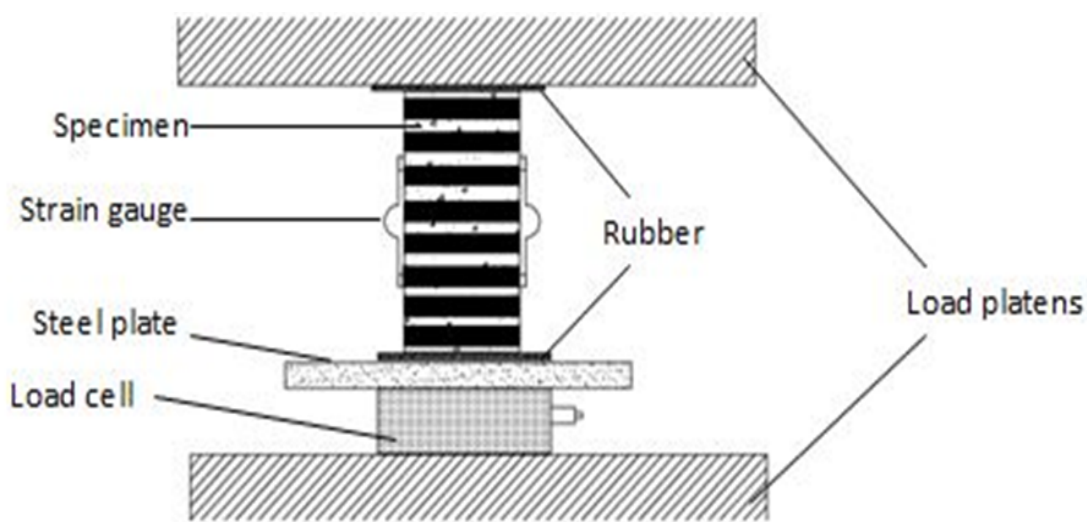

Fig. 2. Compression test setup 


\section{Test results}

\subsection{Failure modes}

It was observed that all of the specimens failed after the steel straps at approximately midheight of the specimen snapped. All specimens failed in the same manner with disregard of pre-damaged levels. No apparent surface cracks were observed during the initial stage of testing ( $<25 \%$ of ultimate load). Minor surface cracks were started to propagate at the midspan of the columns and continued to implode in both upper and lower directions when the load increased to the second stage ( $25 \%-50 \%$ of ultimate load). Thudding sound can be heard at this stage.

The steel straps were observed to prevent the generation of cracks during the third stage ( $50 \%-75 \%$ of ultimate load). A significant thud sound can be heard when ultimate load is approaching but the columns did not fail due to the confining pressure exerted by the steel straps. At ultimate load, minor concrete crushing and disintegration can be observed at approximately mid-span the repaired columns. The columns still remained intact after the failure. Steel strapping has prevented the columns from crushing and collapsing.

Due to the confinement, the columns did not present abrupt failure as control specimen. Obviously, the specimen confined with higher confining volumetric ratio shows remarkably increase in the ductility. It can also be observed that the concrete cores of specimens with higher pre-damaged level are less intact after failure. This can be due to the pre-damaged has caused existing crack and part of the concrete had already partially disintegrated during the pre-damaging process. Fig. 3 shows the failure modes of repaired columns.
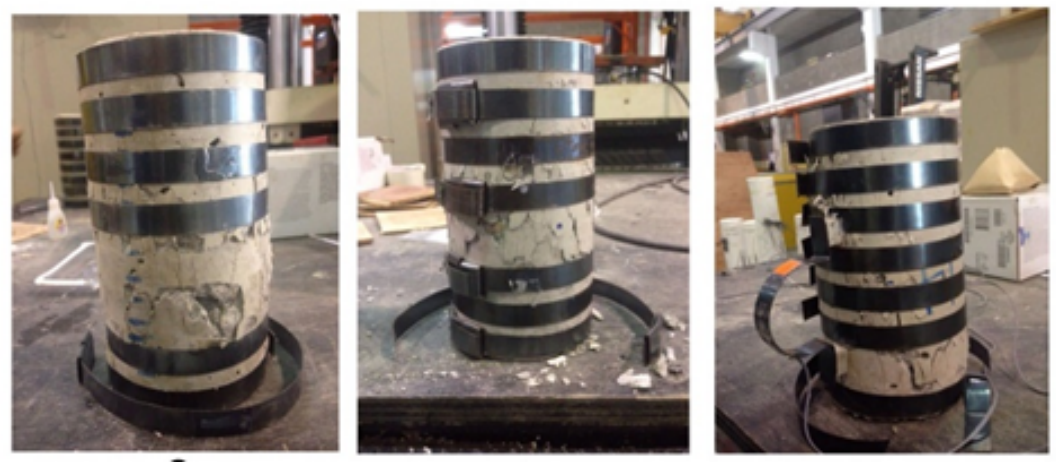

Fig. 3. Failure modes: (a) C50-30-1(+50); (b) C50-10-1(+50); (c) C50-30-2(+50)

\subsection{Stress-strain relationships}

The stress-strain relationships of repairing concrete is shown in Fig. 4. In this figure, the axial stress versus axial strain obtained from the average of the reading from two pi-gauges attached at both sides of the specimens. The figure clearly shows the effectiveness of steel strapping in increasing the performance of damaged concrete. However, it can also be concluded that the existing models which did not considered the pre-damaged levels of concrete are not suitable to be used to predict the stress-strain behaviour of repaired concrete. The accuracy of the existing models in predicting the stress-strain relationships of repaired concrete is further discussed in the following section. The nomenclature of the graph is, C50-30-1(+50) means C50- two $50 \mathrm{~mm}$ omega strain gauges attached at both sides of the specimen, $30 \mathrm{~mm}$ spacing, 1 layer of steel straps, $50 \%$ of pre-damaged level. 


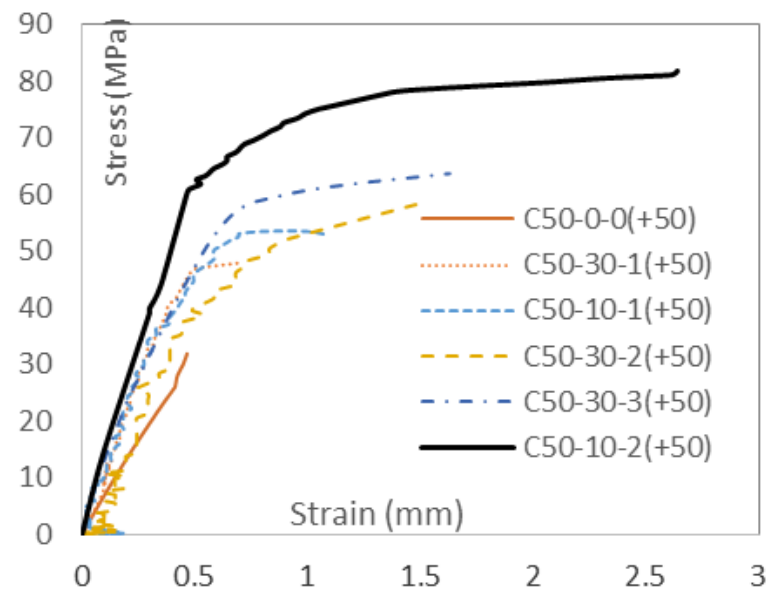

Fig. 4. Load-displacement curves of tested specimens

\section{Summary and conclusion}

A series of experimental studies were performed to investigate the repaired HSC using post-tensioning steel straps confinement. Along the investigation of the behaviour of repaired HSC, several important conclusions which can be drawn are listed follows:

i) The typical failure mode of repaired HSC indicates that the confined HSC failed at the rupture of steel straps resulting immediate loss of confining pressure. Such failure mode is not associated with the variation of confining volumetric ratio or pre-damaged level.

ii) Damaged degree is an important factor and needed to be considered in estimating the ultimate strength and strain of repaired concrete. In general, it was found that the ultimate strength reduced with the increase of concrete damaged degree. Whilst the ultimate strain increased with damaged degree.

iii) Post-tensioning steel straps confinement increase the rigidity concrete damaged at predamaged levels $50 \%$.

This work was funded by Fundamental Research Grant Scheme (FRGS) from Ministry of Higher Education, Malaysia [R.J130000.7822.4F826]. The first author would like to acknowledge that the undergraduate students Amirul Radzi, Melvay Allens and Muhammad Fadhli undertook the tests as their final year projects supervised by the first author.

\section{References}

[1] C.K. Ma, A.Z. Awang, and W. Omar, New theoretical model for SSTT- confined HSC columns, Magazine of Concrete Research, 66(13), 674-684, (2014)

[2] C.K. Ma, A.Z. Awang, R. Garcia, W. Omar, K. Pilakoutas, and M. Azimi, Nominal curvature design of circular HSC columns confined with post-tensioned steel straps, Structures, 7, 25-32,(2016)

[3] C.K. Ma, A.Z. Awang, W. Omar, M. Liang, S-W. Jaw, and M. Azimi, Flexural capacity enhancement of rectangular high-strength concrete columns confined with post-tensioned steel straps: experimental investigation and analytical modelling, Structural concrete, 17(4), 668-676, (2016). 
[4] C.K. Ma, A.Z. Awang, R. Garcia, W. Omar, and K. Pilakoutas, Behaviour of over-reinforced high-strength concrete beams confined with post-tensioned steel straps-an experimental investigation, Structural Concrete, 17(5), 768-777, (2016)

[5] Y. Helal, R. Garcia, K. Pilakoutas, M. Guadagnini, and I. Hajirasouliha, Strengthening of short splices in RC beams using post-tensioned metal straps, Materials and Structures, 49(1-2), 133-147, (2016)

[6] R. Garcia, I. Hajirasouliha, M. Guadagnini, Y. Helal, Y. Jemaa, K. Pilakoutas, P. Mongabure, C. Chrysostomou, N. Kyriakides, A. 1ki, and M. Budescu, Full-scale shaking table tests on a substandard RC building repaired and strengthened with posttensioned metal straps, J. of Earthquake Engineering, 18(2), 187-213, (2014)

[7] H.P. Lee, A.Z. Awang, and W. Omar, Steel strap confined high strength concrete under uniaxial cyclic compression, Construction and Building Materials, 72, 48-55, (2014)

[8] C.K. Ma, A.Z. Awang and W. Omar, Slenderness effect and upper-bound slenderness limit of SSTT-confined HSC column, Int. J. of Structural Engineering, 5(3), 279-286, (2014)

[9] C.K. Ma, A.Z. Awang, and W. Omar, Flexural ductility design of confined highstrength concrete columns: Theoretical modelling, Measurement, 78, 42-48, (2016)

[10] S.M.S. Mohsin, M.F. Manaf, N.N. Sarbini, and K. Muthusamy, Behaviour of reinforced concrete beams with kenaf and steel hybrid fibre, ARPN J. of Engineering and Applied Sciences, 11(8), 5385-5390, (2016)

[11]N.N. Sarbini, I.S. Ibrahim, A.A. Saim, M.A.A. Kadir, and S.S.M. Mohsin, Development of shear stress equation contributed by steel fibre in reinforced concrete, ARPN J. of Engineering and Applied Sciences, 11(8), 5445-5451, (2016)

[12]I.S. Ibrahim, K.S. Elliott, R. Abdullah, A.B.H. Kueh, and N.N. Sarbini, Experimental study on the shear behaviour of precast concrete hollow core slabs with concrete topping, Engineering Structures, 125, 80-90, 2016.

[13]N.N. Sarbini, I.S. Ibrahim, A.A. Saim, A.B. Abdul-Rahman, N.F. Harun, and N.N. Hasbullah, Shear capacity of composite slab reinforced with steel fibre to that of fabric reinforcement in concrete topping, Materials Research Innovations, 18(6), 236-240, (2014) 